Fernández-de-Sevilla, Tomàs (2017). "Growth amid a storm: Renault in Spain during the stagflation crisis, 1974-1985”, Business History 59 (01): 121-140.

\title{
GROWTH AMID A STORM: RENAULT IN SPAIN DURING THE STAGFLATION CRISIS, 1974-1985
}

\begin{abstract}
The aim of this paper is to analyse the trajectory of FASA-Renault during the stagflation crisis. In late 1972, the Spanish government enacted the so-called Ford decrees. The intention was to stimulate specialisation in the European arena by inserting the Spanish subsidiaries within the international strategies of large transnational corporations. In doing so, the effects of the economic crisis were compounded by the restructuring of the sector. The goal is to understand how, in the midst of this situation, FASA-Renault was able to increase production and the size of its workforce, ultimately becoming the leading firm in the sector in terms of production and sales in Spain. This is a remarkable fact due to labour force participation in Spain fell by nearly 3 million people from 1974 to 1985 . The paper argues that FASA-Renault, albeit with nuances, kept its commitment to diversification, neither adopting practices inspired by the production systems of the large Japanese manufacturers nor following the model put forward by the US giants based on large-scale production of a single low- to mid-range car for export.
\end{abstract}

KEYWORDS: Automobile industry; Stagflation Crisis; Spain; Renault; Subsidiaries; Multinationals; Production Systems; Industrial Policies; Labour disputes. 


\section{Introduction}

The period addressed in this paper can be characterised by the exhaustion of a pattern of accumulation, that of post-war growth. The first signs of weakness became noticeable in the late nineteen-sixties and they struck with full force from 1973, spurred on and redoubled by the oil price shocks. ${ }^{1}$ The crisis pervading the European economy was basically industrial in nature. Its outbreak was a severe blow for the automotive industry, marking a breaking point that would lead to important structural changes. ${ }^{2}$

The aim of this paper is to analyse the trajectory of FASA-Renault during the stagflation crisis. In Spain, the outbreak of stagflation was preceded by a shift in industrial policy aimed at reshaping the automotive industry. ${ }^{3}$ During the nineteenfifties, the Franco administration realised that foreign investment represented a 'necessary evil' that Spain would have to countenance for the sake of industrialisation. The trade-off was between a protected home market on one hand and investments and technology on the other. Although the government's objective was to apply a policy of import substitution, Spain lacked the capital and technology to develop growth industries in the second technological revolution. Their implementation could only come at the hands of foreign direct investment through joint ventures with local initiatives. ${ }^{4}$ The appeal of Spain was a protected home market and, given its size, its vast growth potential. As attested by J. Catalan and T. Fernández-de-Sevilla, the takeoff of the automotive industry occurred under a number of industrial policies focused on a market reserve for established producers, a requirement to manufacture with local parts, and an extremely cautious licensing system for manufacturers. ${ }^{5}$ This institutional 
arrangement led to the emergence of a kind of crony capitalism that privileged the ability to control and pull the strings of government ${ }^{6}$, within which FASA-Renault was able to act with maximum effectiveness. ${ }^{7}$

The weakness of the strategy lay in the fact that foreign companies taking part in this type of development process were seldom to manufacture innovative products or to transfer state-of-the-art technology. The reason was that protection enabled them to sell at high prices and large margins, even in the case of mature and obsolete products. This had the result that the products offered by the companies participating in the model found it hard to be competitive in foreign markets. ${ }^{8}$ Once the home market had been filled and lost its vigour, however, exports became the only way to sustain development in the industry. By the end of the sixties, the confirmation of the limitations of domestic demand forced a turning point in Spain's industrial policy. No longer focusing all of its efforts on a policy of import substitution, it started to promote exports. The preferential agreement signed by Spain with the EEC in 1970 signified a reduction in community tariffs on Spanish exports of passenger cars to $3.3 \%$ in 1974. In the wake of the agreement, Ford and GM once again resumed projects that they had abandoned with Franco's victory in the Spanish civil war, their aim now being to use the Iberian Peninsula as a platform for the manufacture of low- to mid-range cars for the European market. Their interests were aligned with those of the Franco administration and their efforts, therefore, were greeted with wholehearted assistance. ${ }^{9}$

In late 1972, the government enacted the so-called Ford decrees. The first decree, issued on 30 November, was justified as necessary to transform the automotive industry in order to increase its exports. The intention was to stimulate specialisation in the European arena by inserting the Spanish subsidiaries within the international strategies of large transnational corporations. The new legislation sought to boost large- 
scale production of some models while maintaining the levels of nationalisation, but it also aimed to promote the manufacture of other models with a lower degree of nationalisation. While the earlier levels of nationalisation were maintained for already established manufacturers, a minimum of $50 \%$ was authorised if they exported vehicles in line with the established general percentages and the value of the imported parts did not exceed $50 \%$ of the value of the exported cars. The decree, in the conditions that it set for the establishment of new enterprises, perfectly suited Ford's wishes: it pegged the minimum nationalisation level at $50 \%$, put the minimum threshold for investment in fixed assets at 10 billion pesetas, established the export percentage at two-thirds of unit production, set the value of imported pieces, parts and other components at no greater than $50 \%$ of the value of the exported cars, and limited year-on-year growth in domestic sales to $10 \%$ of total sales. ${ }^{10}$

The second Ford decree, enacted on 23 December, declared the sector of "preferential interest" and set three fundamental goals: to ramp up plant capacity and production by model, boost exports, and establish advantageous working conditions. The decree included incentives for land expropriation in order to establish or expand plants, tax reductions of up to $95 \%$, and freedom to depreciate new plant and equipment during the first five years. For a company to take advantage of these benefits, it needed to fulfil the following conditions: an average production rate of greater than 500 vehicles per working day; mass production greater than 400 units per day for a basic model or greater than 200 for two models; gross investment in fixed assets greater than 7 billion pesetas, and minimum annual exports at $20 \%$ of production. For already established firms, the deadline for fulfilment of these conditions was set as 1 December 1976.11 
The transformations were many and various. The effects of the economic crisis were compounded by the restructuring of the sector. The aim of this paper is to analyse how FASA-Renault could deal with this situation not only raising its production but also by increasing its staff (which rose from 16,357 to 20,539 employees over the period while the total employees in Spain fell by nearly 3 million people and the unemployment rate shot up from $2.6 \%$ to $21.9 \%$ ), eventually becoming the large car manufacturer in Spain. The aim of this paper is to understand how, in the midst of this situation, FASA-Renault was able to increase production and the size of its workforce (which rose from 16,357 to 20,539 members over the period), ultimately becoming the leading firm in the sector in terms of production and sales in Spain. This is a remarkable fact bearing in mind that labour force participation in Spain fell by nearly 3 million people and the unemployment rate shot up from $2.6 \%$ to $21.9 \%$. Similarly, identifying its growth model is also an aim of the paper, which argues that diversification remained as FASA-Renault main strategy. Neither the production systems of the Japanese carmakers nor the strategy applied by the US giants centred on a single low- to mid-range car for export were applied intensively by the Renault's Spanish subsidiary. FASARenault, albeit with nuances, kept its commitment to diversification, neither adopting practices inspired by the production systems of the large Japanese manufacturers nor following the model put forward by the US giants based on large-scale production of a single low- to mid-range car for export. The research draws on a number of previously unexplored sources of information, such as the minutes of board meetings and of general shareholders' meetings, and on underused sources, such as annual business reports. This information is supplemented with information obtained from the Spanish Association of Car and Lorry Manufacturers (ANFAC, 2003) and the statistical yearbooks of Spain's Directorate-General for Traffic (DGT). ${ }^{12}$ 


\section{Three Years in the Red, 1974-1976}

In early 1973, the Spanish minister of industry set a production target of 1.3 million passenger cars for 1977. Of these, a half-million were to be earmarked for export. ${ }^{13}$ The results for the first quarter of the year, which showed a year-on-year production increase of $17.5 \%$, appeared to confirm the need to scale up capacity in the sector. If the figures for the manufacturers as a whole were good, those of FASARenault, which featured a rise of $34.2 \%$, were even better. FASA, an acronym for Fabricación de Automóviles S.A., had been founded in 1951 with the aim of assembling Renault cars under license in Valladolid, a city located in the centre of the northwestern quadrant of the Iberian Peninsula. ${ }^{14}$ In 1965, it expanded from car assembly to include the manufacture of engines and bodies in Valladolid and gearboxes in Seville. In the same year, Renault became the leading shareholder. ${ }^{15}$ Three years later, the company announced the construction of a second assembly plant in Valladolid. In 1973, only a year after the plant came online, Arturo Fierro, the company's chairman, announced new plans for expansion. The aim was to raise annual production to 340,000 vehicles by 1980, with export levels nearing 30\%. To reach this goal, the construction of a third plant was envisaged for one of the neighbouring provinces. ${ }^{16}$ In 1974 , however, the firm encountered turbulence that brought its projected development plans to a standstill.

The economic crisis that affected Europe's economies from 1974 hit Spain particularly hard. The reasons for this lay in a weaker energy base, a weaker industrial structure and the greater weight of the affected sectors, and these factors were compounded by the amassed rigidities of thirty years of dictatorship and the beginning of political reforms that demanded less stringent adjustment policies. ${ }^{17}$ There were still a number of shortcomings at the structural level, including the greater relative weight of 
industrial sectors with weaker demand, an over-expansion of capital-intensive activities as a result of negative interest rates, an extremely high dependency on technology, and levels of tax revenues as a percentage of GDP that were far below those of western Europe (Catalan, 1999). ${ }^{18}$

Since the application of the national Stabilisation Plan in 1959, the Spanish economy had experienced extremely high annual growth rates ( $8 \%$ on average), which plummeted from 1974 onwards. Until 1978, however, public spending continued to grow annually between $4 \%$ and $5 \%$. The contraction in growth was sharply aggravated by inflation, which began to skyrocket in 1974 and reached a maximum of $24.7 \%$ in 1977, bringing with it the threat of hyperinflation. The economic imbalances were bound up with severe social and political instability. In December 1973, ETA killed Admiral Carrero Blanco, the prime minister of Spain and Franco's heir apparent. Two years later, the dictator himself died and a complicated process of political reform got underway. In 1977, the first legislative elections after the restoration of the monarchy were held and in December 1978 a new constitution was approved. The gradual dismantling of the Franco regime sparked a surge in workers' demands. After the economic boom and wage restraint of the nineteen-sixties, pay levels shot up after the death of the dictator, bearing no relationship to gains in productivity.

In 1974 FASA-Renault embarked on the three poorest years in its history, closing in the red at the end of each fiscal year. The main problems were social and workplace strife and price controls. The continuing growth of the disparity between costs and sales prices limited their ability to manoeuvre and constrained their development process. If the primary cause of rising costs prior to 1975 corresponded to increases in raw materials and intermediate goods, wage costs took centre stage from 1975 onwards, stimulated not only by rampant inflation, but also by acrimonious social 
and workplace strife, which intensified in the autumn of 1974 and did not slacken until the dying days of winter 1976.

The first signs of the cycle of social and workplace conflict affecting FASARenault appeared before the outbreak of the crisis, one more symptom that the Franco regime and the accumulation model of developmentalism were falling into decline. ${ }^{19}$ In 1970 all of the large companies in Spain had a vertical trade union that was the sole agent authorised to engage in collective bargaining on behalf of the workforce. With the start of the decade, however, informal discussion groups sprang up in the Valladolid plants, circumventing the trade union and resulting in shop-floor general assemblies. As Elsie Charron has explained, this clandestine movement coupled labour demands with political struggle in opposition to the regime. ${ }^{20}$

The first actions promoted by these assemblies took place in 1972 and consisted of one and two-hour work stoppages aimed at forcing improvements in the collective bargaining agreement under negotiation. The signing of the agreement, which provided for a nominal wage increase of $15 \%$ for the following fiscal year, restored a certain level of calm. ${ }^{21}$ However, the environment heated up again in 1973 when talks began on a new agreement. In December, protest marches set off from the FASA-Renault plants and ended in the city centre. The measures taken by the workers to exert pressure intensified in January 1974, crystallising in a sit-in strike that affected every facility in the manufacturing complex. Finally, between wages, social security and a reduction in working hours, the new collective bargaining agreement raised labour costs by $22 \%{ }^{22}$

Despite the agreement, the workers in assembly, bodies and deliveries called a work stoppage on 27 September 1974. The strike which, when added to a lockout, lasted nine days, was declared unacceptable by company management, who assigned blame to an "uncontrolled group" and took the decision to lay off 15 workers and levy 
sanctions of various kinds against a further 145 workers. The situation degenerated into a cycle of conflict that worsened with the call for a general strike to be held on 11 December with both political and trade-union ends. In the midst of all of this, a fire in the second assembly plant added even greater strain to the situation. At 5.49 am on the morning of 30 October, a blaze broke out in the plant, causing the death of ten workers and injuries of varying severity to thirty more. ${ }^{23}$ Although the causes of the fire could not be determined, the company's board reported that an expert opinion issued by an international firm specialising in such matters had found "no chance of an accidental cause and no proof of the real cause". ${ }^{24}$ The damage was quantified at 426.8 million pesetas and forced work at the plant to stop for a week. Between the strikes and the fire, FASA-Renault lost roughly 19,000 cars, or $8 \%$ of the scheduled production for the fiscal year. ${ }^{25}$

Although better wages, reductions in working hours and higher social security contributions were negotiated for $1975^{26}$, the industrial conflict became entrenched. Ultimately, the situation erupted in April 1975. When the workers most closely involved in the protests were dismissed, some two thousand workers occupied the assembly plant number two of Valladolid on 22 April and were forcibly removed by the police on the afternoon of 24 April. The police action was followed by a lockout that went on until 2 May, after which the company took the decision to dismiss or suspend without pay over a hundred workers, including several union representatives. ${ }^{27}$

The clear damage to the interests of the company, apparent from the 21 thousand cars that were not produced in the month of April, gradually softened the stance of the board, leading to an incremental return to normality. ${ }^{28}$ Franco's death provided an occasion for an initial relaxation, allowing many of the levied sanctions to be lifted. Following the amnesty decreed on the occasion of the proclamation of Juan Carlos as 
king of Spain, the company's board agreed to grant its own professional amnesty, pardoning all sanctions for events prior to 22 November 1975, although the dismissals were excluded. ${ }^{29}$

In January 1976 the plants in Valladolid saw a new cycle of protests that degenerated into a strike, leading to a new lockout that lasted eight days. As a condition for a return to normality, the workers' assemblies called for the reinstatement of the dismissed workers and of the agreed working hours. ${ }^{30}$ On this last point, the company was more willing to grant concessions, but the board remained intransigent in its stance on the dismissals. ${ }^{31}$ In the end, the magnitude of the losses in the winter of 1976 led management to accept an agreement on working hours that enabled a certain normalisation of activity. ${ }^{32}$

Graph 1 shows the strength of the workers' assemblies. The acrimony of the conflict went hand in hand with the rising weight of labour costs within the company's cost structure. This was an outgrowth not only of the political situation and a crumbling regime that did not have enough power to impose its conditions, but also of the company's need to normalise production in years when it was working at full capacity. The cycle of stoppages and strikes put a severe strain on FASA-Renault because of the cars that it failed to produce and because of the rising costs involved.

Graph 1. FASA-Renault: Weight of labour costs over total costs (\%)

\section{GRAPH 1}

SOURCE: FASA-Renault, Annual Reports, 1972-1986.

The labour conflicts overlapped with the height of the price-cost squeeze, arising from the system of price controls in which the industry operated. Between January 1974 
and June 1975, the cost of stocks rose $31 \%$ while staff costs went up by $48.5 \%$. In return, prices climbed $19.75 \%$, underlining the magnitude of the gap. ${ }^{33}$ The scenario did not vary significantly in the last semester of 1975. A single rise of $10 \%$ was authorised in August, which was once again below the recorded cost increases. Taken together, all of these factors caused FASA-Renault to close all three years from 1974 to 1976 in the red, reporting mounting losses that reached 694 million pesetas in the final year (graph 2).

Graph 2. FASA-Renault: Total net profits (in million ptas) and net profits over turnover $(\%)$

\section{GRAPH 2}

Primary Y-axis: Net profits. Secondary Y-axis: Sales margin.

SOURCE: FASA-Renault, Annual Reports, 1973-1986.

A first consequence of this situation was to halt projected capital spending in May 1974 for a period of two years, most notably postponing the third assembly plant, which the company had decided to build in Palencia, 35 kilometres from Valladolid. ${ }^{34}$ In mid-1974, the board increased share capital by 540 million pesetas, cautioning that this was only the first expansion and that others would be required ${ }^{35}$ However, by the close of the summer, major difficulties in securing finance from Spanish and international banks exacerbated the company's cash shortages. ${ }^{36}$ The losses reported in its income statement forced a suspension of the planned capital infusions and obliged the company to resort to alternative forms of financing. The consequent freeze of its development programme pushed FASA-Renault to operate at the limits of its production capacity. 
The first influx of long-term resources came in mid-1975 from a bond issue of 2.5 billion pesetas. ${ }^{37}$ A year later, once the situation had become stabilised, a second issue of 5 billion pesetas was carried out and this time it was accompanied by an enlargement of share capital by 810 million pesetas charged to the adjustment account. ${ }^{38}$ Despite this, the building works on the third plant did not resume until late 1976, when the provisional liberalisation of prices and the easing of labour strife resulted in sufficient profits to resort to self-financing. ${ }^{39}$

The positive part of the price-cost squeeze was the considerable stimulus it represented for external competitiveness. Cars not only became cheaper in relative terms in the home market, but they also did so in European markets. As a result, the sales price of an R-5 to the public in France in late 1975 was $20 \%$ higher than in Spain. ${ }^{40}$ As graph 3 shows, the exports of FASA-Renault were given a significant boost during its three years in the red.

Graph 3. FASA-Renault: Weight of exports over production and turnover (\%)

GRAPH 3

SOURCE: FASA-Renault, Annual Reports, 1973-1986.

\section{Growth in the midst of the storm, 1977-1980}

In 1977, the state of the Spanish economy was even gloomier than in the preceding three years, particularly from the second quarter of the year. The economic programme of the first government to be elected by universal suffrage since the Second Republic, which was led by the centre-right party Unión de Centro Democrático (UCD) of Adolfo Suárez, a former secretary general of the Francoist single-party Movimiento Nacional, took shape in the so-called Moncloa Pacts concluded in the autumn of 1977. 
These constituted a social pact among all the parties with parliamentary representation and basically consisted of an adjustment policy aimed at curbing inflation in exchange for political and economic reforms. Specifically, they featured a policy of monetary tightening, together with containment of growth in real wages and public spending. ${ }^{41}$

The application of these containment measures succeeded in curbing inflation, although the inflation rate did not fall below 15\% until 1981 and $10 \%$ until 1986. The downside of the austerity policies, however, was a severe contraction in the annual rate of economic growth, which plummeted below $1.5 \%$ until 1986 and sank below zero in 1981. An immediate consequence of stagflation was a collapse in investment, which translated into a sharp fall in labour force participation and the appearance of high unemployment rates, which topped $10 \%$ from $1980 .{ }^{42}$ The economic downturn was accompanied by political instability marked by the crumbling of the centre-right party in power and culminating in the attempted coup d'état of 23 February 1981.

The negative evolution of internal demand particularly affected durable consumer goods like automobiles. Between 1977 and 1980, the home market amassed a negative differential of 85 thousand cars, falling back to 1975 levels. SEAT came out of it worst. Its registrations shrank by more than 100 thousand cars, falling below 1967 levels. The combination of production and registration figures, shown in graph 4, perfectly illustrate how the development of the sector had to rely on high export levels. Once the production increase in 1977 is discounted, because it was entirely down to Ford's activity, the production of the industry as a whole entered into a phase of contraction from which it did not exit until 1983, when Opel began operations.

Graph 4. Production and registrations of passenger cars and light commercial vehicles in Spain (units) 


\section{GRAPH 4}

SOURCE: DGT, Statistical Yearbook and ANFAC (2003).

In 1980 the industry faced an extremely complex situation. While the home market was shrinking for the third consecutive year with no sign of a turnaround in sight, production was being shored up by unprecedented export percentages. Between 1976 and 1977, the ratio of exports to units sold rose by 10 points, climbing to a third of the total. While the devaluation of the peseta accounts for a portion of the increase ${ }^{43}$, the main explanation for it is Ford, which became the leading exporter in Spain. In 1978, exports broke the barrier of 400 million cars, with a growth of $22 \%$ and a percentage of production that surpassed $40 \%$, a level comparable to EEC countries.

Between 1977 and 1980, the hardest years of the crisis, FASA-Renault was able to increase production by more than 100 thousand units and registrations in Spain by more than 20 thousand (graph 5). These figures are striking if we bear in mind that the industry as a whole only increased production by 50 thousand units, while registrations shrank in number by roughly 90 thousand. As a result, FASA-Renault became the leader in production and sales in Spain in 1980.

Graph 5. FASA-Renault: Production and sales of passenger cars and light commercial vehicles in Spain (units)

\section{GRAPH 5}

SOURCE: DGT, Statistical Yearbook and FASA-Renault, Annual Reports.

This was made possible because the firm returned to sound financial standing in 1977, largely due to the success of Renault in France. ${ }^{44}$ The bulk of the moneys were 
sunk into the construction of the third assembly plant, although some also went to various expansion projects in the other plants. The function of the new plant was to satisfy internal demand, launch new models to refresh and expand the range, and permit the earmarking of $30 \%$ of output for export. ${ }^{45}$ The immediate objective was to shake off stagnating production, which was stuck at 900 units a day, raising capacity theoretically to 1200 vehicles a day by 1979 .

Capital spending plans called for new sources of finance capable of providing an annual flow in the region of 7 billion pesetas between 1977 and $1979 .{ }^{46}$ The aim was to secure these funds by increasing share capital, carrying out a bond issue, and obtaining credit. As had already happened in the nineteen-sixties, ${ }^{47}$ a large chunk of the funds came from the Banco de Crédito Industrial (BCI). ${ }^{48}$ In early 1977, the BCI gave a loan of 1.250 billion pesetas and a line of credit of 4 billion pesetas for the following three years. ${ }^{49}$ In addition, FASA-Renault authorised a capital injection of 2.025 billion pesetas. ${ }^{50}$ The austerity measures associated with the Moncloa Pacts and the subsequent credit crunch forced the company's board to complete the expansion in share capital before the end of 1977 , bringing its fully paid-up share capital to 6.075 billion pesetas. ${ }^{51}$

The firm's strong cash position enabled the authorisation, in 1978, of a new capital increase in the amount of 3.0375 billion pesetas, ${ }^{52}$ which took place in April 1979. This was followed a few weeks later by authorisation for a further increase, this time amounting to 4.55625 billion pesetas. ${ }^{53}$ The increase occurred in September 1980 by means of an issue that represented half the authorised amount, bringing the fully paid-up share capital to 11.390625 billion pesetas. ${ }^{54} \mathrm{~A}$ bond issue was also approved for the total amount of 5 billion pesetas for a period of three years. Such a mobilisation of resources, unavoidable to sustain an ambitious development programme, was basically 
made possible by Renault's financial capacity, which covered $95 \%$ of the capital injections. ${ }^{55}$

These efforts enabled the third plant to come online on 2 January 1978. Its concept was based on completely independent buildings for each of the shops, which had work areas on the ground floor and were joined together by means of large open spaces, while the locker rooms and offices were located in separate buildings. The new plant, which was assigned to manufacture the R-12 and R-18, brought together size and diversification, freeing up the second Valladolid plant for the manufacture of the R-5.

When the third plant came online, FASA-Renault became the leading maker of passenger cars in Spain, overtaking SEAT at the top of the sector for the first time in 1980. Success came at the hands of the R-5. The purpose of the model, which started taking shape on the drawing board in 1967 , was to escape the severe doldrums into which the R-4 had fallen because of its failure to compete with models made by Fiat and Volkswagen. However, the man responsible for its design, Bernard Hanon, went further, opting to create a benchmark within the field of second family cars. His diagnosis was clear: growth in the segment would be linked to the entry of women into the automobile market. This is why the R-5 was designed to a sensible and harmonious aesthetic in line with women's preferences. In addition, the design eliminated the two rear doors to make carrying children safer and it incorporated an easy-to-open rear hatchback. The R-5 was the standard-bearer for Renault's new strategy: the range within the range. Within a few years, the firm launched a plethora of versions (L, TL, GTL, LS, TS, GTX, Turbo and Alpine, as well as special editions like the Monte Carlo, Lauréate, Le Car and Campus), which covered a broad swath of the market ranging from $845 \mathrm{cc}$ to $1397 \mathrm{cc}$. The offering doubled in 1980 with the introduction of five doors in all versions. The success was beyond dispute: while the R-5 accounted for 
$30.3 \%$ of Renault sales in France in 1974, the percentage had climbed to $39.8 \%$ by 1981, taking $15.4 \%$ of the French market. ${ }^{56}$

The high demand for the R-5 in Europe, particularly in France, was directly responsible for the impetus given to FASA-Renault's exports. As graph 6 shows, the increase in foreign sales was carried on its shoulders. The destination of Spanish output was Renault's headquarters, from which it was redistributed to its final destination. In terms of foreign sales, the Spanish subsidiary was completely dependent on its parent company.

Graph 6. FASA-Renault: Total exports of whole vehicles and of the R-5 (u/d)

GRAPH 6

SOURCE: Renault Historire, 2011: 127-128.

South of the Pyrenees, the R-5 also had an excellent reception. Launched in November 1972, it proved to have ideal characteristics for the Spanish market, becoming one of the most popular vehicles of the period. In 1975, the range included the TL (956 cc), GTL (1037 cc) and TS (1289 cc) versions, each one aimed at highly differentiated market segments. A year later, the range was expanded with the Copa (1397 cc), whose function was to replace the R-8 TS as an emblem of the sports car segment. As table 1 illustrates, the R-5 represented $40 \%$ of cumulative production between 1974 and 1982. ${ }^{57}$

Table 1. FASA-Renault: Cumulative production by model between 1974 and 1982

\begin{tabular}{cccccccc}
\hline & R-4 & R-6 & R-12 & R-5 & R-7 & R-18 & Total \\
& & & & & & & \\
\hline Units & 328,356 & 202,262 & 332,411 & 940,517 & 159,533 & 187,003 & $2,333,902$
\end{tabular}


$\begin{array}{llllllll}\% & 14.1 & 8.7 & 14.2 & 40.3 & 6.8 & 8.0 & 100\end{array}$

SOURCE: FASA-Renault, Annual Reports, 1974-1982.

In 1980, in the depths of the crisis, the registrations of Renault cars in Spain exceeded 200 thousand units, representing $35 \%$ of total registrations and corresponding to practically all of the vehicles manufactured by FASA. ${ }^{58}$ Without doubt, this achievement was partly the result of the maturity of labour relations at Valladolid. An example of this can be found in the resolution of the conflict that arose in the negotiations of the collective bargaining agreement of 1979. The management stance was not to negotiate their proposal and to tie the application of additional social improvements to the ratification of the new agreement. This sparked stoppages of between 2 and 4 hours a day, which rose to 6 hours when it became apparent that negotiations had ground to a standstill. ${ }^{59}$ The dispute appeared to be on the verge of serious escalation in mid-January when the company presented its offer in writing - an increase of $13 \%$ in the wage bill-a proposal that differed in no way from its initial position, although it did put the announced social benefits in black and white. According to the managing director, despite the collective bargaining committee's willingness to accept the proposal, it was unable to gain approval from the rank and file, described by the managing director as completely radicalised. With things as they were, a thousand workers occupied the number 2 assembly plant and the number 1 engine plant on Tuesday, 6 February, and were forcibly removed by the police two days later. The management response was to impose a lockout on that same Tuesday in the production centres at Valladolid and Palencia, a state of affairs that lasted for a week. The plant lockout resulted in a production shortfall of 17,579 cars that were, however, 
recouped later by lengthening shifts, which kept the losses to levels that management characterised as 'acceptable'. ${ }^{6}$

\section{The storm is only abroad, 1981-1985}

On 4 April 1979, at the same time that SEAT was suffering losses as high as 12 billion pesetas and Ford Spain was forced to hold up a large number of incomplete cars because of strikes in England, the Spanish government undertook an overhaul of automotive legislation. Although the rationale for the new provisions lay in the need to boost production with fewer models, longer series and lower percentages of nationalisation, their main aim was to attract GM. ${ }^{61}$ Three months later, GM Spain was set up with the purpose of manufacturing the Opel Corsa, a model aimed at the same segment as the Fiesta and also designed for the European markets. The leadership of FASA-Renault looked favourably on the intention of the Spanish government, because it recognised that the firm would not survive manufacturing eight different models at an overall rate of 1,200 vehicles a day. ${ }^{62}$ At no time, however, did they consider the possibility of abandoning diversification in favour of a single model.

In the first half of the nineteen-eighties, the automotive industry in Spain reported steady growth in output that co-existed with a severe shrinkage in the home market. The weakness of internal demand can be accounted for by extremely high interest rates and a sluggish rise in household disposable income. In years of serious hardship for the automotive industry in Europe, the sector was forced to sustain its development through export levels that almost no other country was able to match. ${ }^{63}$ The productivity required to fuel competitiveness was achieved by cutting the workforce. Redundancies, temporary layoffs and early retirement, which had been an 
exceptional measure in the industry, became a part of everyday life in the firm over the period.

From 1985 onwards, the Spanish economy had to adapt to imminent entry into the EEC, which entailed a greater openness to the outside-with a tariff reduction of $10 \%$ on 1 March 1986 and another one of $12.5 \%$ on 1 January 1987 -and the introduction of VAT. The increased openness translated into sharp rises in imports as well as stagnating exports. Conversely, the negative dynamic in passenger car registrations was shattered in 1985 with a growth rate of $10 \%$ that climbed to $20 \%$ a year later. By the end of 1986, demand far outstripped supply, causing a disruption in stocks. In that same year, economic growth leapt over the $2 \%$ hurdle for the first time since 1978, announcing the end of the crisis. In addition, employment also reversed its sustained decline for the first time in eleven years. Its healthy performance led to a sharp rise in the consumption of durable goods, which translated into renewed strength in the demand for cars.

FASA-Renault faced the decade of the nineteen-eighties with a new chairman. In October 1979, José Luís Rodríguez-Pomatta, who had replaced Arturo Fierro in 1976, stepped down voluntarily, citing his age as the reason. Manuel Guasch Molins became the first chairman of FASA-Renault to be Renault's pick and his background was distinctly different from that of his predecessors. ${ }^{64}$ Born in Barcelona in 1942, he had a law degree from the University of Valladolid, a degree in economics from the University of Deusto and a master's in international economics from the London School of Economics. In 1966, he had secured a post by public examination in the Spanish state's corps of trade specialists, taking an assignment in the Directorate-General for Foreign Trade and later moving on to the Directorate-General for Tariff Policy and Imports. Meanwhile, in 1982, Pierre Séméréna left the vice-chairmanship of FASA to 
become chairman of Renault Industrial Vehicles, one of the three divisions in which Bernard Hanon, appointed chairman of Renault in 1981, had reorganised the Renault Group. With these moves, both Renault and one of its major divisions were led by men closely linked to FASA-Renault, because Hanon had sat on the board of the Spanish subsidiary since 1976 and served as the sole vice-chairman between 1978 and 1981 .

It fell to the new leadership to maintain the position achieved by the firm. The first major challenge was to confront the entry of GM. The focus was the third quarter of 1982, when the first units of the Corsa were set to roll off the production line. In Valladolid, they did not forget that SEAT had paid dearly when Ford arrived and they were unwilling to absorb the costs of Opel's arrival. In addition, they had to get to grips with the effects of entry into the EEC, especially the progressive liberalisation of the market. The main setback to the interests of FASA-Renault, however, came as a result of the crisis that hit Renault in the first half of the nineteen-eighties. ${ }^{65}$

If FASA-Renault had successfully sidestepped the effects of shrinking demand in the nineteen-seventies, the drop of $11 \%$ in the home market in 1981 caused a similar drop in its sales. Together with a parallel fall in exports, this forced a cutback in its production schedule. In spite of all this, however, the company was able to maintain output above 300 thousand units until 1984, when it shrank by roughly 75 thousand vehicles. Table 2 shows clearly how FASA-Renault's declining share of the Spanish market was not exclusively a product of Opel's entry, but points instead to exports as the main reason for the firm's relative decline.

Table 2. FASA-Renault's share of passenger car production, registrations and exports in Spain with and without Opel (\%) 


\begin{tabular}{lccccccc} 
& & \% without & & \% without & & \% without \\
& \% total & Opel & \% total & Opel & \% total & Opel \\
\hline $\mathbf{1 9 8 2}$ & 32.3 & 33.0 & 35.2 & 36.3 & 27.6 & 28.4 \\
$\mathbf{1 9 8 3}$ & 25.6 & 32.1 & 34.2 & 37.6 & 17.6 & 25.5 \\
$\mathbf{1 9 8 4}$ & 19.1 & 24.1 & 31.3 & 34.4 & 9.1 & 13.0 \\
$\mathbf{1 9 8 5}$ & 18.3 & 23.0 & 31.4 & 35.4 & 8.9 & 12.3 \\
$\mathbf{1 9 8 6}$ & 19.6 & 24.8 & 31.1 & 36.0 & 9.7 & 13.5 \\
\hline
\end{tabular}

SOURCE: FASA-Renault, Minutes of the Board, 1983-1986.

To defend its position, FASA-Renault was forced to become more competitive. Productivity gains were sought by following two strategies: downsizing and capital spending aimed at increased robotics. Primarily, what was new was the reduction in the size of the workforce, whose numbers fell by $10.5 \%$ between 1980 and 1986 . Conversely, progressive market liberalisation compelled the firm to permanently increase its efforts in sales and marketing, with the staff in the sales network increasing by $15 \%$. As a result, the reduction in direct staff as a whole was limited to only 154 employees, leaving the FASA workforce at 19,722 with an additional 16,473 in its sales network. ${ }^{66}$

The first staff cutbacks occurred when the third plant came online. The work requirements of the new plant were largely covered by workers from the Valladolid plants, a practice that was subsequently to continue. ${ }^{67}$ The main cutbacks in workforce, however, took place in 1985 and 1986, when a voluntary redundancy plan with incentives was first instituted, leading to a fall of 1,750 in staff numbers at a total cost of 4.3 billion pesetas in the first year and 4.8 billion pesetas in the second. In addition, temporary work adjustments were applied from 1982 onwards and they intensified in 
the two-year period $1985-86 .{ }^{68}$ The applied measures succeeded in reducing the weight of labour costs to their 1972 levels.

Downsizing was accompanied by increased capital spending on production aimed at escalating the robotics in the plants. In 1985 the Palencia facilities had a 33\% degree of automation and the first assembly plant in Valladolid stood at $25 \% .{ }^{69}$ The efforts to mechanise production also came with an expansion of computer technology in all the company's plants. The first step was to install small computers to provide a real-time solution to receiving stocks and to warehousing. ${ }^{70}$ Shortly afterwards, the firm implemented an application for the launch and control of vehicles, connecting the assembly line with Meconsa, a statistics subsidiary with data centres in Madrid and Valladolid. If the introduction of robotics potentially signified the first steps toward the adoption of practices inspired by the Toyota Production System, ${ }^{71}$ they were nevertheless feeble steps. In addition, in terms of the levels of automation, FASARenault still lagged quite far behind the Opel plant, which was the most automated in Spain.

As noted earlier, shrinking exports was the main problem affecting FASARenault's performance. Although the firm's exports were pushing 100 thousand passenger cars in 1982, sales in France suffered a severe slowdown at the time, because of the crisis confronting Renault and because of the R-5's loss of momentum. The sales cutbacks instituted by Renault were not due to a fall in competitiveness, but rather to its desire to move production from Spain to France. Conversely, FASA-Renault handled the state of affairs in the home market more effectively, showing its capacity to cope with situations in which it had adequate tools to take action. As graph 7 illustrates, despite the fall in market share, the sales network was able to maintain Renault's leadership in Spain, keeping its market share in the region of $30 \%$. 
Graph 7. Sales of passenger cars in Spain by brand

\section{GRAPH 7}

SOURCE: DGT, General Statistical Yearbook, 1974-1985.

In spite of these positive developments, FASA-Renault was negatively affected by the ageing of its range in the first half of the nineteen-eighties. It was a period of transition from the pacesetting models of the seventies, like the R-5 and the R-12, to the models that would leave their mark on the late eighties, like the Super 5 (1985), R-21 (1986), Express (1986) and R-19 (1988). The R-18, launched in late 1978, experienced a clear downward trend from its first complete year of production, reflecting an excessively short life cycle. Similarly, on the next rung below, the R-14 was introduced in late 1979 and it failed dismally in its attempt to become the R-5 of the segment, leading to its withdrawal barely three years after launch. The main explanatory factor for the decline in sales, however, was the premature announcement of the launch of the Super 5, scheduled for 1985 but announced in 1983. The result was that a meagre 27 thousand units of the R-5 were manufactured in 1984, a ridiculous figure when compared to the 140 thousand only two years earlier.

Despite some struggles, FASA-Renault was, together with Ford, the only firm in the sector to stay continuously in the black from 1976 onwards, including in its most critical year, 1984. Further, during the entire crisis, it consistently remained Renault's leading foreign subsidiary. While the figures in table 3 suggest a loss of weight in the international structure of the Renault Group, the fall was solely due to the production carried out in the AMC plant in Kenosha (Wisconsin), which was to cease shortly afterwards. The failure of the US operation once again bolstered FASA-Renault as the 
primary and most successful foreign operation of all those undertaken by Renault in any form. When the crisis came to an end, the Spanish subsidiary was in a position to become one of the main bulwarks of the Renault Group's international strategy, in a new context characterised by specialisation and industrial integration at the European level.

Table 3. Renault's car production outside France

\section{$19751980 \quad 1985$}

FASA-Renault output

$205,934 \quad 341,211 \quad 245,790$

Total foreign output of Renault brand $\quad 568,283 \quad 803,971 \quad 723,281$

FASA-Renault position (ranking)

$\begin{array}{lll}1 & 1 & 1\end{array}$

FASA-Renault share (\%)

$36.2 \quad 42.4 \quad 34.0$

SOURCE: Loubet, 2000: 221.

\section{Conclusions}

During the stagflation crisis that so deeply affected Spain, FASA-Renault was able to combine major investment, which enabled it to increase its production capacity and maintain the size of its workforce, with sustained profits in its income statement. In those years, the company focused its activity in the same direction as the US giants: specialisation in large-scale production of low- to mid-range cars that could be exported to Europe. What was unique to FASA-Renault, however, were the strong results that it achieved in its home market, despite the sharp downturn. Unlike Ford and GM, whose strategy in Spain focused on the manufacture of a single model for export, FASARenault maintained the diversification policy applied by Renault since the nineteen- 
sixties. Having three assembly plants enabled the firm to combine size with diversification, with each plant specialising in one or two specific models.

Between 1974 and 1976, the combination of a series of acrimonious labour disputes and a legal framework that impeded rising costs from having a direct impact on car prices led to mounting losses at FASA-Renault. An initial consequence was that its development programme ground to a halt, with the main victim being the forestalled construction of a third assembly plant. As a result, the production rate was stymied at a time when the company was proving itself to be the most efficient and dynamic player in the sector, preventing it from fully capitalising on the upswing that it was experiencing.

The social and labour stability that was achieved in mid-1976 enabled the firm to revive its plans for expansion. The construction of a third plant permitted FASARenault to become the leading company in the sector in Spain for the first time. Rising production, which shot up from slightly over 200 thousand cars in 1976 to nearly 350 thousand in 1980, took place in the worst years of the economic crisis. This upward trend was made possible because of its excellent performance in domestic sales and in exports. Indeed, the modest increases in domestic sales in a shrinking market enabled Renault to account for a third of all registrations by 1980, making it the leading brand in Spain. A large part of these outstanding results should be ascribed to the excellent reception of the Renault 5, which was perfectly suited to the circumstances of the time and which, therefore, became known ultimately as the "car of the crisis".

Once FASA-Renault had become the leading firm in the sector and the brand leader in Spain, its challenge was to defend its position. At the domestic level, its biggest threat was the arrival of Opel, although the effects of entry into the EEC must be considered as well. The main problems, however, came from the crisis that Renault 
went through in France during the first half of the nineteen-eighties and that led to a standstill in its exports. However, FASA-Renault resisted remarkably well in its home market, demonstrating its ability to handle areas under its direct responsibility. Its strategy revolved around consensual adjustments agreed with its workforce and around increasing automation. In addition, FASA-Renault never lost its position as the leading production subsidiary of the Renault Group. With its numbers returning to black in 1977, the firm became the only one in sector, besides Ford, not to experience losses during the rest of the period under analysis.

\section{AKNOWLEDGEMENTS:}

Financial support from project HAR201564769-P (Ministerio de Economia y Competitividad, Gobierno de España, and ERDF, European Union) is gratefully aknowledge.

\section{References}

ANFAC. 1977-2002, Madrid: ANFAC, 2003.

Bonin, Hubert, Yannick Lung and Steven Tolliday (Eds.). Ford, 1903-2003: The European History. Paris: Plage, 2003.

Boyer, Robert, Elsie Charron, Ulrich Jürgens and Steven Tolliday (eds.). Between Imitation and Innovation. The transfer and Hybridization of Productive Models in the International Automobile Industry. Oxford: Oxford University Press, 1998.

Boyer, Robert and Michelle Freyssenet. Les modèles productifs, París: La Découverte, 2000.

Brenner, Robert. The Economics of Global Turbulence. London: Verso, 2006. 
Carreras, Albert and Xavier Tafunell. Historia económica de la España contemporánea. Barcelona: Crítica, 2004.

Catalan, Jordi. "Spain, 1939-96". In Western Europe: Economic and social change since 1945 edited by Max-Stephan Schulze, 353-371. London: Longman, 1999.

Catalan, Jordi. "La creación de la ventaja comparativa en la industria automovilística española, 1898-1996”. Revista de Historia Industrial, 18 (2000): 113-155.

Catalan, Jordi. "Strategic policy revisited: The origins of mass production in the motor industry of Argentina, Korea and Spain, 1945-87’. Business History, 52 no. 2 (2010): 207-230.

Catalan, Jordi. "From the Great Depresión to the Euro Crisis, 1929-2013: A Global Approach”. Revista de Historia Industrial, 56 (2014): 15-45.

Catalan, Jordi \& Tomàs Fernández-de-Sevilla. "Die staatliche Industriepolitik und die Entwicklung der Automobilindustrie in Spanien 1948-1985”. In Automobilindustrie 1945-2000. Eine Schlüsselindustrie zwischen Boom und Krise, edited by Stephanie Tilly and Florian Triebel, 255-284. München: Oldenbourg, 2013.

Catalan, Jordi and Alex Sánchez, A. "Cinco cisnes negros. Grandes depresiones en la industrialización moderna y contemporánea”. In Crisis económicas en España, 1300-2012, edited by Francisco Comín and Mauro Hernández, 83-112. Madrid: Alianza, 2013.

Charron, Elsie. «FASA-Renault: Innovation in Productive Flexibility and Job Security". Between Imitation and Innovation. The transfer and Hybridization of Productive Models in the International Automobile Industry edited by Robert Boyer, Elsie Charron, Ulrich Jürgens and Steven Tolliday, 254-277. Oxford: Oxford University Press, 1998. 
De la Torre, Joseba and Mario García-Zuñiga. "El impacto a largo plazo de la política industrial del desarrollismo español”. Investigaciones de Historia Económica, 9 no. 1 (2013): 43-53.

De la Torre, Joseba and Mario García-Zuñiga. "Was it a Spanish Miracle? Development plans and regional industrialization, 1950-1975”. In Industrial Policy in Europe after 1945: Wealth, Power and Economic Development in the Cold War edited by Christian Grabas and Alexander Nutzendale, 162-183. New York: Palgrave, 2014. Dirección General de Tráfico (DGT). Anuario Estadístico General, 1974-1985.

Eichengreen, Barry. The European Economy since 1945. Princeton: Princeton University Press, 2007.

FASA-Renault, Minutes of the Board, 1970-1986.

FASA-Renault, Minutes of the Shareholders' Meetings, 1974-1986.

FASA-Renault, Annual Reports, 1970-1986.

Fernández-de-Sevilla, Tomàs. "Industrializando la España interior: El ensamblaje del Renault 4CV en la FASA de Valladolid, 1951-1958”. Investigaciones de Historia Económica, 18 (2010): 133-162.

Fernández-de-Sevilla, Tomàs. "Renault in Spain: From Assembly to Manufacture, 1961-1972”. Business History, 52 no. 3 (2010): 471-492.

Fernández-de-Sevilla, Tomàs. "Inside the Dynamics of Industrial Capitalism: The Mass Production of Cars in Spain, 1950-1985”. Revista de Historia Economica-Journal of Iberian and Latin America Economic History, 32 no. 2 (2014): 287-315.

Fernández-de-Sevilla, Tomàs. "La emergencia del capitalismo industrial en España: FASA-Renault y la triple inversión, 1965-1974”. Revista de Historia Industrial, 55 (2014): 135-168. 
Freyssenet, Michel. "Renault: From Diversified Mass Production to Innovative Flexible Production". In One Best Way? Trajectories and Industrial Models of the World's Automobile Producers edited by Michel Freyssenet, Andrew Mair, Kiochi Shimizu and Giuseppe Volpato, 365-394. Oxford: Oxford University Press, 1998.

Freyssenet, Michel, Andrew Mair, Kiochi Shimizu, and Giuseppe Volpato (eds.). One Best Way? Trajectories and industrial models of the world's automobile producers. Oxford: Oxford University Press, 1998.

García Ruiz, José L. “La evolución de la industria automovilística española, 1946-1999: una perspectiva comparada". Revista de Historia Industrial, 19-20 (2001): 133163.

Guillen, Mauro. The Limits of Convergence: Globalization and Organizational Change in Argentina, South Korea and Spain. Princeton: Princeton U. P, 2001.

Haggard, Stephan. Pathways from the Periphery: The politics of growth in newly industrializing countries, Cornell: Cornell UP, 1990.

Loubet, Jean-Louis. Renault. Histoire d'une Enterprise. Boulogne-Billancourt: ETAI, 2000.

Loubet, Jean-Louis. Histoire de l'automobile française. Paris: Seuil, 2001.

Mair, Andrew. "Honda's Global Flexifactory Network”. International Journal of Operations \& Production Management, 14 no. 3 (1994): 6-22.

Moral, José A. "Les années 70: une décision courageuse". Renault Histoire (special number: 1908... Plus de cent ans de Renault en Espagne), (2011): 73-77.

Ohno, Taiichi. "How the Toyota production system was created". Japanese Economic Studies, 10, no. 4 (1982): 83-101.

Renault Histoire. “1908... Plus de cent ans de Renault en Espagne”. Special number, 2011. 
Rojo, Luis A. "La Crisis de la Economía Española, 1973-1984”. In La economía española en el siglo XX. Una Perspectiva Histórica edited by Jordi Nadal, Albert Carreras and Carles Sudrià, 190-200. Barcelona: Ariel, 1994.

Rowthorn, Bob and Andrew Glynn. "The Diversity of Unemployment Experience since 1973”. In The Golden Age of Capitalism. Reinterpreting the Postwar Experience edited by Stephen Marglin and Juliet Schor, 218-266. Oxford: Clarendon, 1990.

Sako, Mari. "Suppliers' Associations in the Japanese Automobile Industry: Collective Action for Technology Diffusion”. Cambridge Journal of Economics, 20 no. 6 (1996): 651-671.

Shimizu, Kiochi. Le toyotisme, París: La Découverte, 1999.

Studer-Noguez, Isabel Ford and the Global Strategies of Multinationals. London: Routledge, 2002.

Sudrià, Carles. “Ajuste económico y transición política (1975-1985)”. In España en crisis. Las grandes depresiones económicas, 1348-2012 edited by Enrique Llopis and Jordi Maluquer, 193-219. Barcelona: Pasado y Presente, 2013.

Trullen, Joan. Fundamentos Económicos de la transición política española. Madrid: Centro de Publicaciones del Ministerio de Trabajo y Seguridad Social, 1993.

Womack, James P., Daniel T. Jones, and Daniel Roos. The machine that changed the World. New York: Rawson Associates, 1990.

Woodward, Nicholas. "The Search for Economic Stability: Western Europe since 1973”. In Western Europe. Economic and Social Change since 1945 edited by Max-Stephan Schulze, 63-80. London: Longman, 1999. 
Table 1. FASA-Renault: Cumulative production by model between 1974 and 1982

\begin{tabular}{cccccccc}
\hline & R-4 & R-6 & R-12 & R-5 & R-7 & R-18 & Total \\
\hline Units & 328,356 & 202,262 & 332,411 & 940,517 & 159,533 & 187,003 & $2,333,902$ \\
$\%$ & 14.1 & 8.7 & 14.2 & 40.3 & 6.8 & 8.0 & 100 \\
\hline
\end{tabular}

SOURCE: FASA-Renault, Annual Reports, 1974-1982. 
Table 2. FASA-Renault's share of passenger car production, registrations and exports in Spain with and without Opel (\%)

\begin{tabular}{cccccccc}
\hline & \multicolumn{2}{c}{ Production } & \multicolumn{2}{c}{ Registrations } & \multicolumn{2}{c}{ Exports } \\
\cline { 2 - 8 } & \multicolumn{3}{c}{ \% without } & & \% without & & \% without \\
& \% total & Opel & \% total & Opel & \% total & Opel \\
\hline $\mathbf{1 9 8 2}$ & 32.3 & 33.0 & 35.2 & 36.3 & 27.6 & 28.4 \\
$\mathbf{1 9 8 3}$ & 25.6 & 32.1 & 34.2 & 37.6 & 17.6 & 25.5 \\
$\mathbf{1 9 8 4}$ & 19.1 & 24.1 & 31.3 & 34.4 & 9.1 & 13.0 \\
$\mathbf{1 9 8 5}$ & 18.3 & 23.0 & 31.4 & 35.4 & 8.9 & 12.3 \\
$\mathbf{1 9 8 6}$ & 19.6 & 24.8 & 31.1 & 36.0 & 9.7 & 13.5 \\
\hline
\end{tabular}

SOURCE: FASA-Renault, Minutes of the Board, 1983-1986. 
Table 3. Renault's car production outside France

\begin{tabular}{lccc}
\hline & $\mathbf{1 9 7 5}$ & $\mathbf{1 9 8 0}$ & $\mathbf{1 9 8 5}$ \\
\hline FASA-Renault output & 205,934 & 341,211 & 245,790 \\
Total foreign output of Renault brand & 568,283 & 803,971 & 723,281 \\
FASA-Renault position (ranking) & 1 & 1 & 1 \\
FASA-Renault share (\%) & 36.2 & 42.4 & 34.0 \\
\hline
\end{tabular}

SOURCE: Loubet, 2000: 221. 
Graph 1. FASA-Renault: Weight of labour costs over total costs (\%)

SOURCE: FASA-Renault, Annual Reports, 1972-1986.

Graph 2. FASA-Renault: Total net profits (in million ptas) and net profits over turnover $(\%)$

Primary Y-axis: Net profits. Secondary Y-axis: Sales margin.

SOURCE: FASA-Renault, Annual Reports, 1973-1986.

Graph 3. FASA-Renault: Weight of exports over production and turnover (\%) SOURCE: FASA-Renault, Annual Reports, 1973-1986.

Graph 4. Production and registrations of passenger cars and light commercial vehicles in Spain (units)

SOURCE: DGT, Statistical Yearbook and ANFAC (2003).

Graph 5. FASA-Renault: Production and sales of passenger cars and light commercial vehicles in Spain (units)

SOURCE: DGT, Statistical Yearbook and FASA-Renault, Annual Reports. 
Graph 6. FASA-Renault: Total exports of whole vehicles and of the R-5 (u/d)

SOURCE: Renault Historire, 2011: 127-128.

Graph 7. Sales of passenger cars in Spain by brand

SOURCE: DGT, General Statistical Yearbook, 1974-1985.

${ }^{1}$ Key analyses of the stagflation crisis can be found in Rowthorn and Glynn "The Diversity of Unemployment Experience since 1973"; Woodward "The Search for Economic Stability"; Brenner The Economics of Global Turbulence; Eichengreen The European Economy since 1945; and Catalan "From the Great Depression to the Euro Crisis".

${ }^{2}$ Key analyses on the structural changes in the automotive industry can be found in Womack et al. The machine that changed the World; Freyssenet et al. One Best Way?; Boyer et al. Between Imitation and Innovation; and Boyer \& Freyssenet Les modèles productifs.

${ }^{3}$ Key analyses of the stagflation crisis in Spain can be found in Rojo "La Crisis de la Economía Española"; Catalan "Spain, 1939-96"; Carreras \& Tafunell Historia económica de la España contemporánea; Catalan \& Sánchez "Cinco cisnes negros" and Sudrià "Ajuste económico y transición política”.

${ }^{4}$ See Guillen The Limits of Convergence.

${ }^{5}$ Catalan "Strategic policy revisited"; Catalan \& Fernández-de-Sevilla "Die staatliche Industriepolitik und die Entwicklung der Automobilindustrie in Spanien"; and Fernandez-de-Sevilla "Inside the Dynamics of Industrial Capitalism". An in-depth analyse of the industrial policy applied in Spain is offered in De la Torre \& García-Zuñiga “Was it a Spanish Miracle?".

${ }^{6}$ De la Torre \& García-Zuñiga "El impacto a largo plazo de la política industrial del desarrollismo español".

7 Fernández-de-Sevilla "Industrializando la España interior" and "La emergencia del capitalismo industrial en España".

${ }^{8}$ See, among others, Haggard Pathways from the Periphery. 
${ }^{9}$ The shift in automobile policy is highlighted in Catalan "La creación de la ventaja comparativa en la
industria automovilística española" and García Ruiz "La evolución de la industria automovilística
española".
${ }^{10}$ Boletín Oficial del Estado (BOE), 7/12/1972. The Ford's global strategy is explained in Studer-Noguez Ford and the Global Strategies of Multinationals. An indispensable analysis of the Ford strategy in Europe is offered in Bonin et al. (eds.) Ford: The European History.

${ }^{11}$ BOE, 29/1/1973.

${ }^{12}$ ANFAC (2003), 1977-2002, and DGT, Anuario Estadístico General.

${ }^{13}$ FASA-Renault, Minutes of the Board (thereafter FRMB), 12/04/1973. The minister set the new goals in the Barcelona International Motor Show.

${ }^{14}$ The origins of FASA are analysed in Fernández-de-Sevilla "Industrializando la España interior".

${ }^{15}$ The transition from assembly to manufacture can be found in Fernández-de-Sevilla "Renault in Spain".

${ }^{16}$ FRMB, 22/11/1973. Burgos, Palencia and Salamanca were the provinces analyzed in the study.

${ }^{17}$ Rojo, p. 192.

${ }^{18}$ Catalan “Spain, 1939-96", p. 369.

${ }^{19}$ Developmentalism is the common term used to refer to the economic growth model adopted in Spain during the 1960s.

${ }^{20}$ Charron "FASA-Renault: Innovation in Productive Flexibility and Job Security", p. 259.

${ }^{21}$ FASA-Renault, Minutes of the Shareholders' Meeting (thereafter FRMSM) 14/06/1972.

${ }^{22}$ FRMB, 22/03/1974.

${ }^{23}$ FRMB, 29/11/1974. Three of the people dead were employees of FASA-Renault and the rest were workers of El Sol, a cleaning company to which FASA-Renault had hired cleaning services.

${ }^{24}$ FRMSM, 26/06/1975. Recently, Juan A. Moral "Les années 70: une décision courageuse", p.75 has explained that the direction of FASA-Renault received a blackmail demanding 50 millions of pesetas to be left in a certain park in Valladolid, otherwise the assembly factory II would be burned. A camouflage police officer attended the meeting and nobody else showed up. The fire took place just a few hours later.

${ }^{25}$ FRMSM, 26/06/1975.

${ }^{26}$ FRMB, 31/01/1975. Pierre Séméréna, manager of the company, stated that these measures represented a wage cost increase of more than $30 \%$.

${ }^{27}$ FRMSM, 26/06/1975. 
${ }^{28}$ FASA-Renault, Annual Report (thereafter FRAR), 1975.

${ }^{29}$ FRMB, 4/12/1975.

${ }^{30}$ FRMB, 27/1/1976.

${ }^{31}$ FRMB, 27/04/1976.

${ }^{32}$ FRMB, 27/04/1976. The Board estimated a decrease of 20,840 vehicles in 1976, meaning a reduction in turnover of 3,000 millions of pesetas and a loss of 700 millions of pesetas.

${ }^{33}$ FRMB, 26/06/1975.

${ }^{34}$ FRMB, 17/05/1974.

${ }^{35}$ FRMSM, 20/06/1974. The corporate capital amounted to 3,240 millions of pesetas.

${ }^{36}$ FRMB, 27/09/1974.

${ }^{37}$ FRMSM, 26/06/1975.

${ }^{38}$ FRMSM, 27/04/1976.

${ }^{39}$ FRMB, 14/12/1976.

${ }^{40}$ FRMB, 3/10/1975.

${ }^{41}$ Trullen Fundamentos Económicos de la transición política española, pp.71-82.

${ }^{42}$ Carreras \& Tafunell, p. 367. In six years, between 1977 and 1985, investments had negative growth rates, reducing the employed population from 12.8 to 10.6 million, with an unemployment rate of $21.9 \%$.

${ }^{43}$ Carreras \& Tafunell, p. 367. The imbalance in the balance of payments forced a devaluation of $10 \%$ of the peseta over the dollar in 1976 and of $20 \%$ in 1977.

${ }^{44}$ Freyssenet, pp. 366-371; Loubet Histoire de l'automobile française, pp. 277-342.

${ }^{45}$ FRMSM, 22/06/1976.

${ }^{46}$ FRMSM, 22/06/1978. In 1977, inversions amounted to 7,180 millions of pesetas, from which around $60 \%$ was allocated to Palencia, whereas amortized assets amounted to 3,076 millions of pesetas.

${ }^{47}$ Fernández-de-Sevilla "La emergencia del capitalismo industrial en España".

48 The BCI was constituted at the end of the WWI as the institution of the large Spanish bankers to provide long-term industrial financing. It was nationalized by the Franco's regime in 1962 and reconverted in its tool for the promotion of the indicative planning.

${ }^{49}$ FRMB, 26/01/1977.

${ }^{50}$ FRMSM, 22/06/1977.

${ }^{51}$ FRMB, 23/11/1977. 
${ }^{52}$ FRMSM, 22/06/1978.

${ }^{53}$ FRMSM, 19/06/1979.

${ }^{54}$ FRMB, 29/09/1980.

${ }^{55}$ FRMB, 9/09/1979.

${ }^{56}$ Loubet, Renault. Histoire d'une Enterprise, pp. 175-176.

${ }^{57}$ The R-18, a three-box saloon with a 1.7-litre engine, was the only model introduced from 1977 to 1981. Launched in September 1978, its sales was placed at 30,000 units over the next seven years, thus becoming the second best selling model for Renault in the Spanish market.

${ }^{58}$ Dirección General de Tráfico, Anuario Estadístico General. Only 458 Renault cars were imported in 1980.

${ }^{59}$ FRMB, 20/02/1979.

${ }^{60}$ FRMB, 9/10/1979.

${ }^{61}$ Among other measures, Spain's sales to manufacturers installed in Spain after 1972 were limited by decree to a maximum of $10 \%$ out of the total registered units in the previous year. This restriction disappeared in 1983, first full year of GM Spain production.

${ }^{62}$ FRMB, 30/04/1979.

${ }^{63}$ ANFAC, pp. 294-295. In 1985, exportations accounted for $63 \%$ of total production in the sector, $62 \%$ in Germany, 56\% in France, 36\% in Italy and 22\% in the UK.

${ }^{64}$ FRMB, 9/10/1979.

${ }^{65}$ The crisis of Renault in the early eighties is detailed in Freysenet, pp. 380-383; and Loubet, pp._284299.

${ }^{66}$ FRAR, 1974 and 1986. FASA-Renault had a staff of 16,357 workers in 1974 and its sales network employed 9,513 workers.

${ }^{67}$ As Charron, pp. 263-267 has pointed out, the transfer of surplus workers from Valladolid to Palencia was the basis on which work stability was based.

${ }^{68}$ FRAR, 1985 and 1986. In 1985 temporary work adjustments affected 10,135 people for an average of 32 days, representing a cost of 1,430 milion of pesetas for the company. One year later, the reduction of working time affected 5,000 people for an average of 14 days and at a cost of 380 million of pesetas.

${ }^{69}$ FRAR, 1985.

${ }^{70}$ FRAR, 1980 and 82. In 1982, 150 computers had been installed on production and business network. 
${ }^{71}$ Key analyses on Japanese production systems can be found in Ohno "How the Toyota production system was created"; Womack et al.; Mair "Honda's Global Flexifactory Network"; Sako "Suppliers' Associations in the Japanese Automobile Industry"; Shimizu Le toyotisme; and Boyer \& Freyssenet. 